\title{
Design of Microcontroller Programming Learning KIT Using Scratch for Arduino
}

\author{
Yulisman', Uci Rahmalisa ${ }^{2}$ \\ ${ }^{1,2}$ Sistem Informasi, STMIK Hang Tuah Pekanbaru
}

\begin{tabular}{l} 
Article Info \\
\hline Article history: \\
Received 11 14, 2021 \\
Revised 12 10, 2021 \\
Accepted 12 13, 2021 \\
\hline
\end{tabular}

\section{Keywords:}

Scratch for Arduino

Prototype

Learning KIT

Microcontroller.

\begin{abstract}
Based on the results of the researcher's observations, the competence of students' skills in the subjects of Microprocessors and Microcontrollers is still lacking. This is due to the fact that the current learning method is still using the conventional method, and still using conventional program code writing model. It is difficult to understand for students who are beginners in the field of programming. The purpose of this research is to produce Learning KIT products to facilitate learning activities of Microcontroller programming with Plug and Play system, in writing program code was made easy with simply compiling instructions in the form of block puzzles. It can make easy for the beginner to understand programming logic and algorithms. The method steps taken refer to prototyping method, it aims to get an overview of the tool's designed and built to be shown to the user. The evaluation prototype will be used as a reference to make a tool as the final product as the output of this research.
\end{abstract}

This is an open access article under the CC BY-SA license.

\section{Corresponding Author:}

Yulisman

Sistem Informasi

STMIK Hang Tuah Pekanbaru

J1.Mustafa Sari No.5 Tangkerang Selatan

Email: yulisman@htp.ac.id

(C) The Author(s) 2021

\section{Introduction}

On the website psmk.kemdikbud.go.id/ in 2018 study text, the demand for policy reform in the middle of century, Industrial revolution 4.0 based on cyber physical system, all of data, devices, machines and humans in industrial field be able to connect and communicate through a platform was connected to the internet or called IoT (Internet of Thing). This requires teachers to be more creative in using theoretical and practical learning tools to make students easily understand the presented material to improve student competence.

In the regulation of the Minister of National Education Number 23 of 2006, item 23 states that the competency standards for SMK graduates include mastering the competence of skills and entrepreneurship programs to fulfil work demands or to continue study. To support the achievement of these graduate competency standards, quality learning is needed. One of the efforts to improve the quality of learning, including the use of learning media. In the subjects of the Department of Electronics Engineering, in the content of vocational specialization for basic skill programs, there are programming, microprocessor and microcontroller engineering subjects.

When doing the microcontroller programming practicum, students are faced with two problems, namely: 1) Hardware preparation, students must assemble electronic components according to the circuit to be made on the breadboard (prototype board), besides that the circuit display is not neat because of the use of jumper cables, after doing in practicum, all electronic components used must be disassembled for storage, this is unefficient in terms of practicum time, besides that electronic components are susceptible to damage if 
disassembly and installation activities are carried out continuously. 2) The programming interface software used is still conventional, so the display is less attractive, and the beginner's students will have difficulty understanding conventionally written programming instruction blocks. For more details, let's look at the comparison picture of conventional learning models with learning models using the Microcontroller Learning KIT (Device/Equipment) both from the Hardware and from the Software.

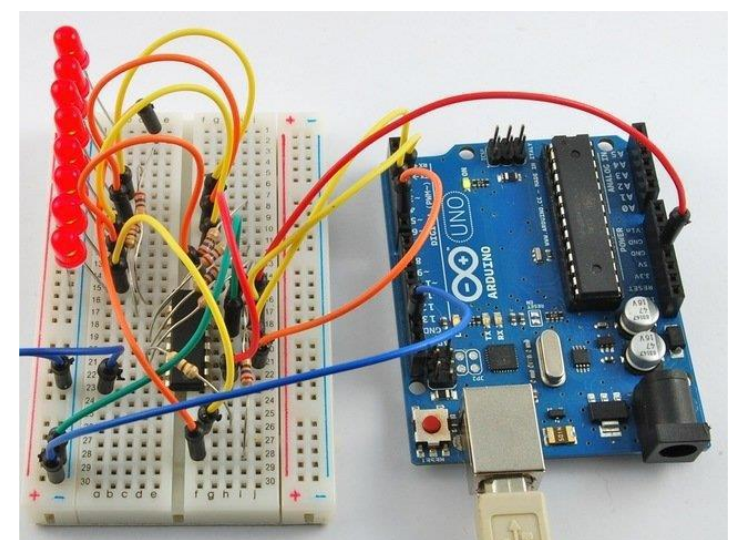

Figure 1 Preparation of Conventional Project Series

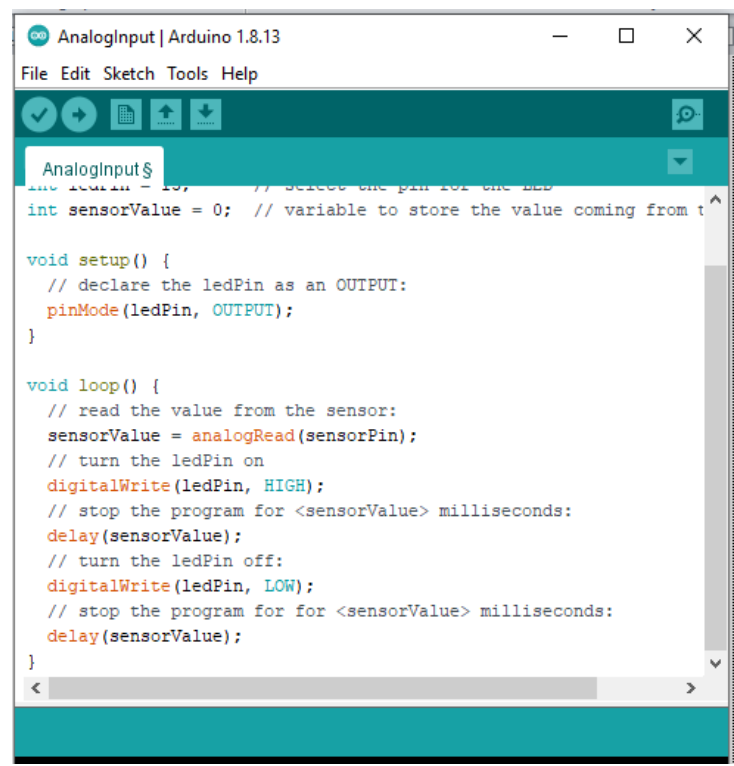

Figure 2 Conventional Programming Interface

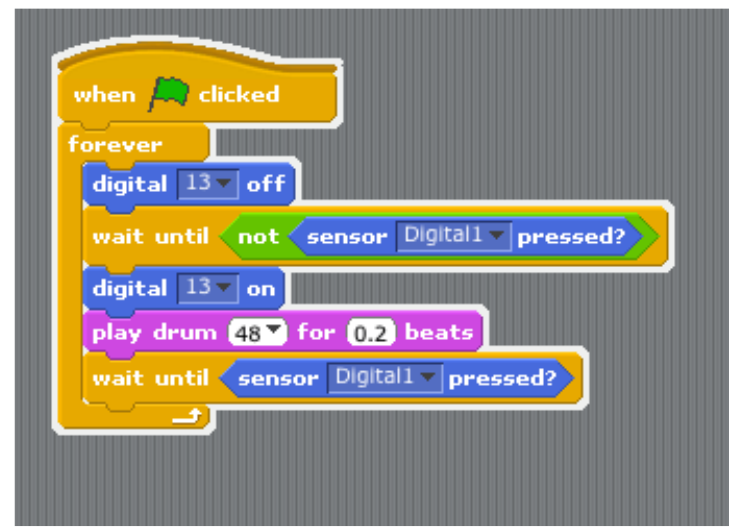

Figure 3 Block Puzzle Based Programming Interface 
Based on the description of the problem above, it is necessary to conduct the research in producing an effective and efficient Microcontroller Learning KIT product with the title "Design and Build Microcontroller Programming KIT Starter Using Scratch for Arduino" to improve the quality of education, especially in the field of microcontroller programming. The results of this research also an effort to improve the quality of human resources in facing the challenges in the Industrial Revolution Era 4.0. It is preparing the younger generation to be able to develop various prototypes or technological devices IoT-based.

\section{Research Method}

Methodology for Systems Development is standard process development teams to link all the steps needed to analyze, to design, to implement, and to maintain IS. The methodology is still suitable to be used as a guide in system development is SDLC. The System Development Life Cycle (SDLC) is the methodology used to develop, to maintain, and/or to replace IS. In this research, it will use prototype model, this model was chosen because in this research, it will build a prototype first, and then implement it. This models can be used to connect customer misunderstandings about technical matters and clarify the specifications of the customer's desired requirements to application makers [10]. The steps of the Prototype model are:

1. The researcher will collect the data needed in the tool-making process, and this step is the first step to find a problem formulation related to how to design and build a Microcontroller Programming Learning KIT Using Scratch for Arduino. The resulting output is a Learning KIT product.

2. The researcher will make a prototype to give an idea to the customer how the final result of the product to be made. The following is an example of the prototype that will be generated:

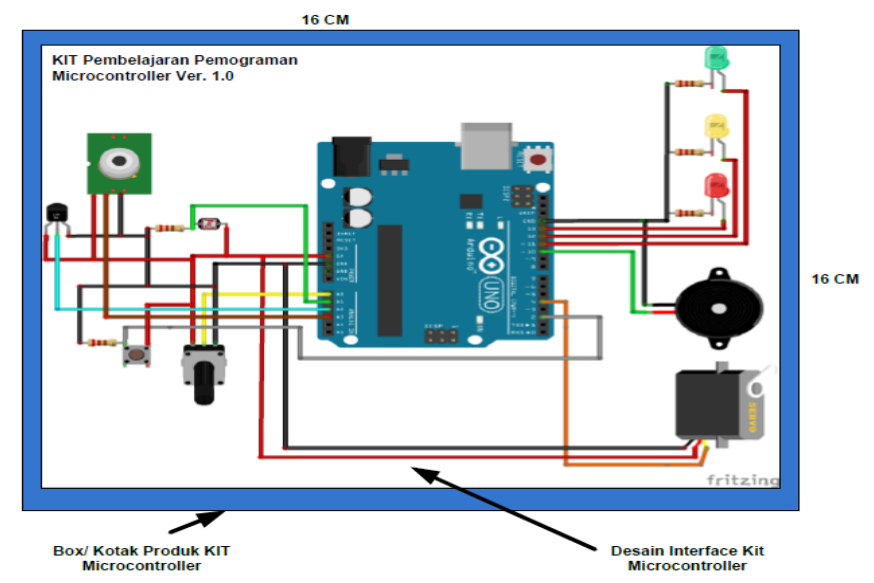

Figure 4 Learning KIT design seen from above

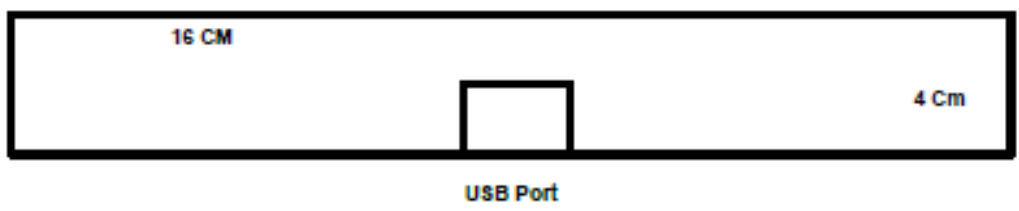

Figure 5 KIT design seen from the side

The following is an overview of the Learning KIT Layout Design that will be made: 


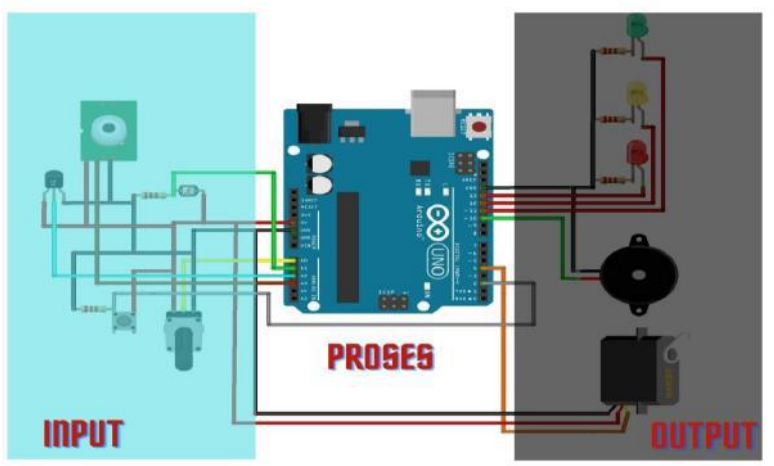

Figure 6 Microcontroller Learning KIT Series

Information :

a. This microcontroller learning KIT series consists of 3 main circuits (Input, Process, and Output)

b. The input circuit consists of a light sensor (LDR), a temperature sensor (LM35), a motion sensor (HC-SR501) and a variable resistor (Potensio and Push Button).

c. The main assembly of the processing unit uses an Arduino Uno Board with an ATMEGA32 Microcontroller.

d. The Output Circuit, it consists of 3 LEDs (Red, Yellow, and Green), a 5v Buzzer, and a Servo Motor.

3. The last step that will be done is demonstration of the tool and testing of the tool to ensure the tool runs according to its function properly.

To see the achievement of these outcomes, a test of the use of tools will be carried out in the schools that have been determined. This tool will also be accompanied by a module or manual book for using the tool to make easy for users to apply it.

\section{Result and Discussion}

The results of the research entitled "Designing a Microcontroller Programming Learning KIT Using Scratch for Arduino" are as follows:

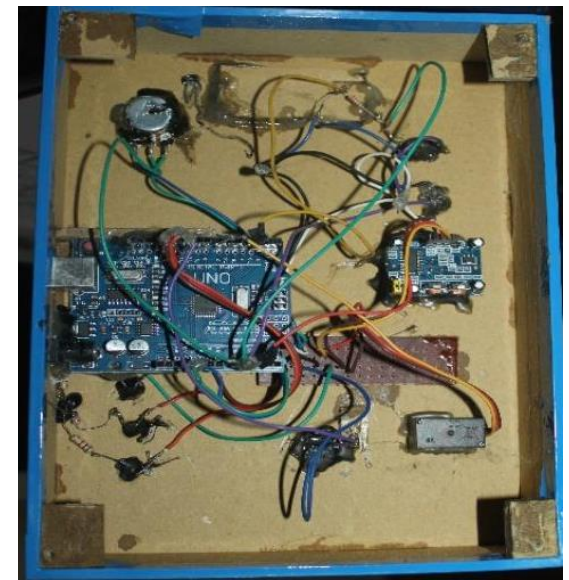

Figure 7. The results of Learning KIT series seen from inside

Information :

a. The input circuit consists of a light sensor (LDR), a temperature sensor (LM35), a motion sensor (HC-SR501) and a variable resistor (Potensio and Push Button).

b. The main circuit of the processing unit uses an Arduino Uno Board with an ATMEGA32 microcontroller.

c. The Output Circuit, it consists of 3 LEDs (Red, Yellow, and Green), a 5v Buzzer, and a Servo Motor. 
For more details, the layout of the circuit can be seen from the front view of the KIT Microcontroller as follows:

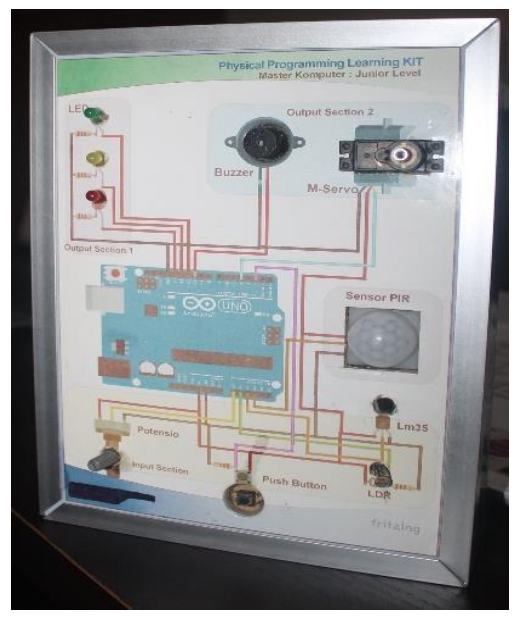

Figure 8. Microcontroller KIT Series seen the front

\section{Testing Result}

Testing on this tool is done by running programming exercises have been prepared on the LKS directly with the KIT that has been made. The following is a description of the results of the KIT Microcontroller test with the Student Worksheet (LKS) that has been compiled. In this case, the researcher tested all the activities in the LKS. The testing steps are:

1. Pair the KIT and Cable on a PC with a Windows operating system that has Arduino and Scratch for Arduino software installed. This application is the needs to teach students without coding. The preparation of instructions is done by compiling Puzzles. This is very good for junior level children.

2. After all the devices are installed, see in the LKS what programming will be made. This worksheet can be developed again for several meetings as the needs of the teacher.

3. After practicing between the exercises in the LKS and the KIT, the program is carried out in accordance with the expected results in the LKS.

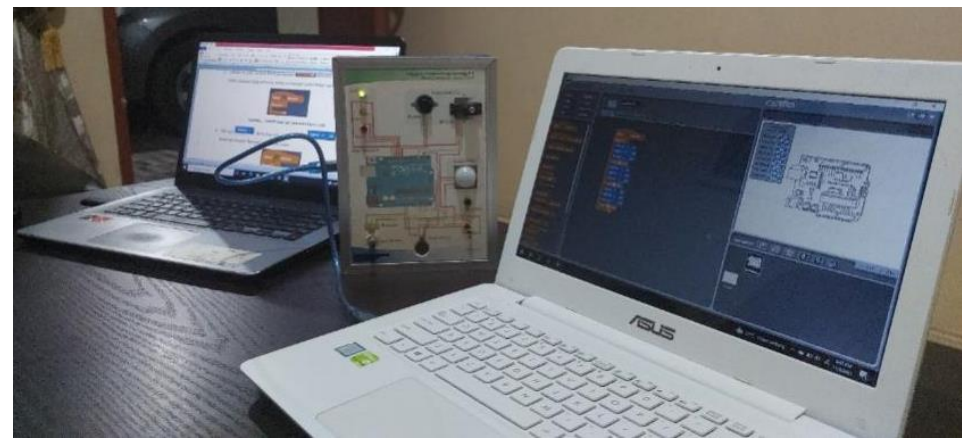

\section{Conclusion}

Figure 9 Microcontroller Programming KIT Testing Process

In the research entitled Design of Microcontroller Programming Learning KIT Using Scratch for Arduino has been conducted testing, the following conclusions can be drawn:

1. The results of the research in the form of a Microcontroller Programming KIT can interact with the Scratch for Arduino application

2. All sensors as input media and output devices (actuators) used in this circuit can work according to the commands given through the Scratch for Arduino application. 
3. Through this Microcontroller Programming KIT, teachers and students will experience an interesting learning atmosphere, it makes the class not boring, because the Scratch for Arduino application is also equipped with simple animation creation.

4. This Microcontroller KIT can be used for more than 15 types of projects or case examples in the field of basic microcontroller programming.

The suggestion from this research is it will be hoped that the Microcontroller KIT can be developed again by adding sensors such as liquid, gas, sound and other sensors, so that the learning objectives of the microcontroller can be achieved.

\section{Acknowledgement}

We would like to thank the related parties who have given us the opportunity to conduct research, facilitate our research process to completion until we finally publish the results of our research journal.

\section{References}

[1] A. Kadir, Pemrograman Arduino dan Processing. Elex Media Komputindo, 2017.

[2] A. Kadir, Stratch for Arduino (S4A). Yogyakarta: C.V Andi Offset, 2016.

[3] D. Nahrowi, D. Aribowo, and M. A. Hamid, "Pengembangan Trainer Kit Mikrokontroler ATMega16 untuk Sekolah Menengah Kejuruan,” J. Pendidik. Teknol. dan Kejuru., vol. 17, no. 2, pp. 145-155, 2020.

[4] Dinata, Y. M. (2016). Arduino Itu Pintar. Elex Media Komputindo.

[5] Febriani, A., \& Irawan, Y. (2021). Detector Leakage Gas Lpg Based On Telegram Notification Using Wemos D1 and Mq-6 Sensor. Journal of Robotics and Control (JRC), 2(4), 287-291.

[6] Linarta, A. (2020). RANCANG BANGUN APLIKASI ABSENSI DAN PENGGAJIAN PADA KANTOR KPU MENGGUNAKAN FRAMEWORK LARAVEL (STUDI KASUS: KPU KABUPATEN BENGKALIS). Journal of Technopreneurship and Information System (JTIS), 3(3), 86-91.

[7] H. A. Dharmawan, Mikrokontroller: Konsep Dasar dan Praktis. Universitas Brawijaya Press, 2017.

[8] Mustaqim, I. (2016). Pemanfaatan Augmented Reality sebagai media pembelajaran. Jurnal Pendidikan Teknologi dan Kejuruan, 13(2), 174-183.

[9] Rahmalisa, U., Mardeni, M., Helmi, R., \& Linarta, A. (2020). Pemberi makan otomatis pada kucing menggunakan raspberry pi berbasis android. Jurnal teknologi dan open source, 3(2), 298-308.

[10] Radillah, T., Widodo, P. P., \& Linarta, A. (2017, November). Aplikasi Optimalisasi Layanan Kunjungan Rutan Klas IIB Dumai Berbasis Sms Auto Response (SAR). In Prosiding Seminar Nasional (Vol. 1, No. 1, pp. 150-164).

[11] Sugiarto, M. I., Linarta, A., \& Sofiyan, A. (2019). Aplikasi Layanan Informasi Absen dan Nilai Berbasis SMS Gayeway Menggunakan PHP pada SMK Taruna Persada Dumai. Informatika, 9(2), 60-69.

[12] S. Pendidikan et al., "Pengembangan Trainer Robot Transporter Dengan Aplikasi Android Berbasis Arduino Untuk Mata Pelajaran Mikroprosesor Dan Mikrokontroller Di Smk Negeri 1 Driyorejo Puput Wanarti Rusimamto Abstrak," pp. 363-367.

[13] T. Sutabri, Analisis sistem informasi. Andy, 2016 